\title{
ARBITRAGEM E MÉTODO DE ARBITRAMENTO DE PREÇO: UMA ANÁLISE SOBRE O ACÓRDÃO PROFERIDO PELO SUPERIOR TRIBUNAL DE JUSTIÇA NOS AUTOS DO RECURSO ESPECIAL N. 1.569.422 - RJ
}

\section{ARBITRATION AND THE PRICING METHOD: A ANALYSIS ABOUT THE HIGH COURT DECISION RULED BY THE "SUPERIOR TRIBUNAL DE JUSTICA" (A COURT ABOVE THE STATE'S COURTS IN BRAZIL) IN THE APPEAL N. 1.569.422 - RJ}

\section{Ciro Rangel Azevedo ${ }^{1}$}

Resumo: O presente artigo buscar examinar os fundamentos do acórdão proferido pelo Superior Tribunal de Justiça nos autos do Recurso Especial n. 1.569.422 - RJ, que apreciou a questão relativa à existência de cláusula compromissória em disposição contratual que delegava a terceiro a atribuição de decidir, em caráter definitivo e vinculante, acerca da fixação do preço de participação acionária no caso de exercício de Opção de Venda.

Palavras-chaves: Cláusula compromissória. Forma. Arbitration. Arbitrador. Preço. Opção de venda.
Abstract: The article has sought to scrutinize the grounds that were the foundation for the holding of the "Superior Tribunal de Justiça" (a court above the state's courts in Brazil) in the appeal n. 1.569.422 - RJ, that analyzed the issue related to the existence of a binding clause under a contract that delegated to a third party the duty to decide, in a final and binding decision, about the price fixation of the shares if the option for a sale was exercised.

Key words: Binding clause. Shape. Arbitration. Arbitrator. Price. Option of Sale.

1 Mestrando em Direito Civil na Pontifícia Universidade Católica de São Paulo (PUC/ SP). Pós-Graduado em Direito Empresarial pela Fundação Getúlio Vargas Direito Rio (FGV). Advogado. E-mail: ciro.azevedo@adv.oabrj.org.br 


\section{INTRODUÇÃO}

A arbitragem vem ganhando significativo espaço no cenário jurídico brasileiro, especialmente em razão das vantagens proporcionadas por este método alternativo de solução de controvérsias, a saber, a confidencialidade, especialidade dos julgadores em relação à matéria e a celeridade. Contudo, a arbitragem deve ser fruto da escolha inequívoca das partes contratantes, já que implica, necessariamente, na renúncia à jurisdição estatal.

Nesse contexto, os princípios da autonomia privada e do consensualismo assumem grande importância em matéria de arbitragem, respaldando a livre e inequívoca escolha das partes contratantes de submeter à jurisdição arbitral controvérsias acerca de direitos patrimoniais disponíveis.

Como é cediço, a convenção de arbitragem representa o gênero do instituto, que admite 2 (duas) espécies, quais sejam, a cláusula compromissória e o compromisso arbitral. A primeira representa o acordo das partes por meio do qual se comprometem a submeter potencial controvérsia futura advinda de uma relação-jurídico contratual subjacente à apreciação de árbitro (s), cuja decisão será final para as partes. O segundo, por sua vez, materializa o acordo das partes no sentido de submeter à jurisdição privada controvérsia já deflagrada e existente, cuja decisão final será igualmente definitiva e vinculante.

Em contratos paritários, a Lei n. 9.307/96 ("Lei de Arbitragem") exige que a cláusula compromissória seja estipulada por escrito, podendo estar inserta no próprio contrato ou instrumento apartado a que ele se refira. Este é o teor e comando do Art. $4^{\circ}, \S 1^{\circ}$, da Lei de Arbitragem.

Já em relação aos contratos de adesão, a Lei de Arbitragem traz exigências adicionais, disciplinando que a cláusula compromissória somente terá eficácia se o aderente tomar a iniciativa de instituí-la ou concordar, de forma expressa, com 
a sua instituição por escrito em documento anexo ou em negrito, com a assinatura ou visto especialmente para esta cláusula. A diferenciação do regime jurídico dos contratos paritários e dos contratos de adesão, em matéria de arbitragem, será importante para o presente artigo.

O compromisso arbitral, por sua vez, deve atender aos requisitos previstos no Art. $9^{\circ}, \S \S 1^{\circ}$ e $2^{\circ}$ da Lei de Arbitragem, conforme se tratar de compromisso arbitral judicial ou extrajudicial. O compromisso arbitral, no entanto, não será abordado no presente artigo.

Especificamente sobre a questão da forma, como será abordado, discute-se se a exigência de forma escrita representa elemento da essência da cláusula compromissória, constituindo, pois, requisito de validade, ou apenas elemento de prova, apto a servir de instrumento para demonstrar a existência desta modalidade de convenção de arbitragem. Sobre este ponto, perfilhamos o entendimento segundo o qual o requisito da forma escrita tem natureza meramente ad probationem.

Como será abordado, o instituto da arbitragem não se confunde com outros institutos previstos no ordenamento jurídico. Com efeito, não se pode confundir a arbitragem com as técnicas de mediação e conciliação, assim como a arbitragem em nada tem a ver com o instituto previsto no art. 485 do Código Civil em vigor, que trata da figura do arbitrador/avaliador. Esta diferenciação, considerando a sua importância para o presente artigo, será detalhadamente aqui explorada.

Feito este breve apanhado do instituto da cláusula compromissória, trazemos à atenção do leitor o acórdão proferido pelo STJ, nos autos do Recurso Especial n. 1.569.422 - RJ ("Acórdão"), que, ao apreciar caso concreto de negócio jurídico em que foi estipulada previsão atribuindo a terceiro a tarefa de avaliar, em caráter definitivo e vinculativo, preço de mercado de participação acionária objeto de alienação em sede de 
contrato de opção de venda ("put"), julgou no sentido de atribuir natureza de cláusula compromissória à referida previsão, julgando extinto o processo submetido à corte pelo autor da demanda em razão da alegação, pelos réus, da existência de convenção de arbitragem ${ }^{2}$.

O presente artigo traz abordagem sobre o Acórdão proferido pelo STJ, explorando os fundamentos adotados pela egrégia corte-responsável pela uniformização da interpretação da lei federal no ordenamento jurídico brasileiro. Essa abordagem explorará as questões relativas à forma da alegada cláusula compromissória de arbitragem adotada pelas partes contratantes e, principalmente, buscará compreender o efetivo conteúdo e alcance da disposição que serviu de base para a decisão do STJ.

\section{O ACÓRDÃO DO STJ}

$\mathrm{O}$ presente artigo tem por objeto o acórdão proferido pelo STJ nos autos do Recurso Especial n. 1.569.422 - RJ, de relatoria do Ministro Marco Aurélio Bellizze, julgado em 26/04/2016 e publicado em 20/05/2016 ("Acórdão"). Eis a ementa do referido julgado, de relevância em matéria de arbitragem, in verbis:

RECURSO ESPECIAL. CLÁUSULA COMPROMISSÓRIA VEICULADA EM DOCUMENTO APARTADO DO INSTRUMENTO CONTRATUAL SUBJACENTE (MEIO EPISTOLAR). APOSIÇÃO DE ASSINATURA NO DOCUMENTO. DESNECESSIDADE. ANUÊNCIA INEQUÍVOCA SOBRE A CONVENÇÃO DE ARBITRAGEM. RECONHECIMENTO. DISPOSIÇÃO CONTRATUAL QUE DELEGA A TERCEIRO A SOLUÇÃO DE ESPECÍFICA CONTROVÉRSIA (VALOR DA PARTICIPAÇÃO ACIONÁRIA A SER ADQUIRIDA), CUJA DECISÃO SERIA FINAL, DEFINITIVA E ACATADA PELAS PARTES. CLÁUSULA COMPROMISSÓRIA, AINDA QUE VAZIA, APTA A SUBTRAIR DO PODER JUDICIÁRIO

2 Consoante atual art. 485, VII, do CPC/2015. 
O JULGAMENTO DA QUESTÃO. EFEITO NEGATIVO. OBSERVÂNCIA. PRETENSÃO ACERCA DO CUMPRIMENTO DA OBRIGAÇÃO ASSUMIDA. RESISTÊNCIA DA PARTE DEMANDADA. INEXISTÊNCIA. EXTINÇÃODO PROCESSO, SEM JULGAMENTO DE MÉRITO. NECESSIDADE. RECURSO PROVIDO.

1. Sob o aspecto formal, a única exigência tecida pela lei de regência para o estabelecimento da convenção de arbitragem, por meio de cláusula compromissória-em não se tratando de contrato de adesão, é que esta se dê por escrito, seja no bojo do próprio instrumento contratual, seja em documento apartado. $O$ art. $4^{\circ}$ da Lei $n$. 9.307/96 não especifica qual seria este documento idôneo a veicular a convenção de arbitragem, não se afigurando possível ao intérprete restringir o meio eleito pelas partes, inclusive, v.g., o meio epistolar. Evidenciada a natureza contratual da cláusula compromissória (autônoma em relação ao contrato subjacente), afigura-se indispensável que as partes contratantes, com ela, consintam.

1.1 De se destacar que a manifestação de vontade das partes contratantes, destinada especificamente a anuir com a convenção de arbitragem, pode se dar, de igual modo, de inúmeras formas, e não apenas por meio da aposição das assinaturas das partes no documento em que inserta. Absolutamente possível, por conseguinte, a partir do contexto das negociações entabuladas entre as partes, aferir se elas, efetivamente, assentiram com a convenção de arbitragem.

2. Por meio da cláusula compromissória, as partes signatárias ajustam convenção de arbitragem para solver eventuais conflitos de interesses, determinados ou não, advindos de uma relação contratual subjacente, cuja decisão a ser prolatada assume eficácia de sentença judicial. Desse modo, com esteio no princípio da autonomia da vontade, os contratantes elegem um terceiro-o árbitro, que pode ser qualquer pessoa que detenha, naturalmente, a confiança das partes -, para dirimir, em definitivo, a controvérsia a ele submetida. Como método alternativo de solução de litígios, o estabelecimento da convenção de arbitragem produz, de imediato, dois efeitos bem definidos. O primeiro, positivo, consiste na submissão das partes à via arbitral, para solver 
eventuais controvérsias advindas da relação contratual subjacente (em se tratando de cláusula compromissória). O segundo, negativo, refere-se à subtração do Poder Judiciário em conhecer do conflito de interesses que as partes tenham reservado ao julgamento dos árbitros.

2.1 Afigura-se absolutamente possível que as partes, por anteverem futuras e pontuais divergências ao longo da consecução do objeto contratual, ou por conveniência/necessidade em não se fixar, de imediato, todos os elementos negociais, ajustem, no próprio contrato, a delegação da solução de tais conflitos a um terceiro ou a um comitê criado para tal escopo e, também com esteio no princípio da autonomia de vontades, disponham sobre o caráter de tal decisão, se meramente consultiva; se destinada a resolver a contenda imediatamente, sem prejuízo de a questão ser levada posteriormente à arbitragem ou à Justiça Pública, ou se vinculativa e definitiva, disposição contratual que, em qualquer circunstância-ressalvado, por óbvio, se existente algum vício de consentimento,--deve ser detidamente observada.

2.2 Será, portanto, a partir da natureza conferida pelas partes à decisão do terceiro ou do comitê criado para o escopo de dirimir determinada controvérsia, respeitada a autonomia dos contratantes, é que se poderá inferir se se está, ou não, diante de um método alternativo de heterocomposição de conflitos de interesses.

2.3 No caso, para a específica divergência quanto aos valores das ações a serem adquiridas, as partes avençaram que a correlata decisão do terceiro/árbitro seria final, definitiva e aceita pelas partes, o que encerra, inarredavelmente, convenção de arbitragem, ainda que vazia, a merecer,necessariamente, o respaldo do Poder Judiciário. Para tal propósito, é irrelevante o termo utilizado na avença ("avaliador", "arbitrador", etc).

3. As demandadas reconhecem, sem qualquer ressalva, a obrigação de adquirir a participação acionária, assumida por ocasião do acordo de unificação das companhias de navegação, nos moldes dispostos na Primeira Carta a ele anexada, não se eximindo, é certo, de seu cumprimento. Pugnam, tão-somente, que se observe a integralidade das 
disposições insertas na aludida correspondência, notadamente em relação ao valor das ações a serem adquiridas, no que reside propriamente a controvérsia, cuja solução, como visto, foi atribuída à arbitragem, de modo definitivo e irrevogável, de modo a subtrair do Poder Judiciário o julgamento da questão. Ressai evidenciado, no ponto, a própria ausência do interesse de agir.

3.1 A jurisdição estatal, caso haja resistência de qualquer das partes em implementar a arbitragem convencionada-o que, por ora, apenas se pode atribuir ao próprio demandante-poderá, como visto, ser acionada para o exclusivo propósito de efetivar a instauração da arbitragem, a quem caberá solver a controvérsia reservada pelas partes, conforme dispõe o art. $7^{\circ}$ da Lei n. 9.307/96.

4. Recurso especial provido, para extinguir o processo sem julgamento de mérito. (Grifo nosso).

Votaram juntamente com o Ministro Relator Marco Aurélio Bellizze, os Srs. Ministros Paulo de Tarso Sanseverino e Moura Ribeiro. Vencidos os Srs. Ministros Ricardo Villas Bôas Cueva e João Otávio de Noronha.

Para a adequada reflexão sobre este precedente, decidido por maioria de votos, é importante descrever, mesmo que de forma resumida, os fatos relativos ao caso concreto apreciado pelo STJ. Em apertada síntese, o conflito gira em torno da pretensão do autor, Sr. Hugo, doravante denominados apenas "Autor", de compelir os réus (HaakonLorentzen, Erling Sven Lorentzen e Lorentzen Empreendimentos S.A.), doravante denominados apenas "Réus", a adquirirem a participação acionária por ele detida na sociedade Norsul, conforme previsão constante em Carta-Compromisso, instrumento epistolar anexo ao Acordo de Unificação de sociedades de navegação, negócio jurídico devidamente assinado entre as partes contratantes.

A Carta-Compromisso, frise-se, integrante do r. Acordo de Unificação como anexo, disciplinava mecanismo de Opção de Venda ("put") em favor do Autor segundo o qual os Réus, por 
mero ato de comunicação do Autor acerca do exercício da opção estipulada em seu favor, se obrigaram a adquirir 7\% do capital social da Companhia de Navegação Norsul de titularidade do Autor. De acordo com a referida Carta-Compromisso, caso as partes não chegassem a consenso dentro do prazo de 30 (trinta) dias quanto ao valor de mercado para a aquisição das ações de emissão da Norsul de titularidade do Autor, seria adotado procedimento em que seriam nomeados avaliadores para a apuração do preço das ações na ocasião do exercício da Opção de Venda, cuja decisão teria caráter definitivo e vinculativo às partes. Eis o teor da referida disposição da Carta-Compromisso:

Caso não seja acordado tal valor dentro de 30 (trinta) dias, as partes nomearão dois avaliadores (um indicado por cada parte), que apontarão um terceiro, se necessário for, e no prazo de no máximo 60 (sessenta) dias apresentarão o valor de mercado para a (s) Empresa (s). A decisão dos avaliadores será final, definitiva e acatada pelas partes. (Grifo nosso).

O Autor, lastreado na referida disposição, comunicou às contrapartes acerca do exercício da sua Opção de Venda, deflagrando o início das tratativas para operacionalizar a transferência de sua participação acionária. Neste ponto, vale ressaltar que entre as partes contratantes não há controvérsia quanto à prerrogativa conferida ao Autor para transferir a sua participação acionária e, ainda, em relação à obrigação das contrapartes de promoverem a efetiva aquisição. Ou seja, a Opção de Venda não é ponto controverso. Portanto, a controvérsia reside no valor de mercado das ações de emissão da Norsul, objeto da transferência, e, ainda, na base de cálculo do percentual (7\%) da participação acionária detida pelo Autora ser adquirida pelos Réus.

As tratativas das partes não lograram sucesso, o que motivou a propositura de ação judicial pelo Autor em face dos Réus, tendo como objetivo (i) a declaração judicial de que os Réus se obrigaram, por meio da Primeira Carta (documento 4), a adqui- 
rir ações ordinárias da Norsul, de titularidade do Autor, equivalentes a 7\% (sete por cento) do capital social da Nova Norsul; (ii) a apuração do valor de mercado da Norsul, tal como descrito na Primeira Carta, por meio de perícia técnica a ser determinada pelo juízo; e (iii) condenação dos demandados a cumprir a obrigação assumida em Carta-Compromisso emitida em 14 de setembro de 1995, em que se comprometeram a adquirir 7\% das ações ordinárias de titularidade do Autor, emitidas pela Companhia de Navegação Norsul, da qual também são acionistas.

Em contestação, as contrapartes - os Réus - alegaram a existência de convenção de arbitragem na Carta-Compromisso, documento anexo ao Acordo de Unificação de sociedades de navegação, cuja disposição, devido a sua substancial relevância para o presente estudo, vale a pena ser novamente transcrita, in verbis:

Caso não seja acordado tal valor dentro de 30 (trinta) dias, as partes nomearão dois avaliadores (um indicado por cada parte), que apontarão um terceiro, se necessário for, e no prazo de no máximo 60 (sessenta) dias apresentarão o valor de mercado para a (s) Empresa (s). A decisão dos avaliadores será final, definitiva e acatada pelas partes. (Grifo nosso).

Em 1 ${ }^{a}$ Instância, o juízo da $4^{\text {a }}$ Vara Empresarial do Rio de Janeiro rejeitou a alegação em sede de despacho saneador, sob o seguinte fundamento de que não constava dos autos a concordância expressa do aderente, nos termos do art. $4^{\circ}$ da Lei de Arbitragem. Interposto o Agravo de Instrumento, ao qual foi negado seguimento. Após rejeição de Embargos de Declaração, foi interposto o Recurso Especial, acerca do qual o STJ deu provimento para declarar extinto o processo. Os principais fundamentos do STJ foram os seguintes:

1. Tendo em vista que não se trata de contrato de adesão, já que celebrado entre agentes em condições paritárias, a Carta-Compromisso se insere no conceito de documen- 
to apartado previsto no art. $4^{\circ}, \S 1^{\circ}$, da Lei de Arbitragem, atendendo ao requisito legal de forma escrita;

2. As Partes pactuaram a eleição de terceiros para definição da controvérsia acerca do preço de mercado da Norsul, atribuindo eficácia vinculativa e definitiva à decisão dos avaliadores, o que denota o intuito de celebrar convenção de arbitragem, sendo irrelevante a adoção da nomenclatura "avaliador", "arbitrador" etc.

3. Por força do princípio da competência-competência, as questões relativas à existência, validade e eficácia da cláusula compromissória devem ser apreciadas com precedência pelo juízo arbitral.

Nesse contexto, o presente artigo tem por objetivo abordar os referidos argumentos trazidos pelo STJ, com enfoque nas seguintes indagações: (i) o instrumento intitulado Carta-Compromisso, anexo ao Acordo de Unificação, tem aptidão de preencher o requisito legal acerca da forma da convenção de arbitragem?; (ii) qual o papel da forma na convenção de arbitragem?; (iii) a disposição acima transcrita da Carta-Compromisso pode ser entendida como cláusula compromissória ou se trata de disposição absolutamente distinta?; (iv) o princípio da competência-competência é aplicável ao caso concreto?

\section{FORMA E CONVENÇÃO DE ARBITRAGEM}

Como negócio jurídico que é, a cláusula compromissória deve ser estudada à luz da teoria tricotômica do negócio jurídico, isto é, deve ser submetida à técnica da eliminação progressiva, a qual impõe que o negócio jurídico deve ser analisado em 3 (três) planos, a saber, os planos da existência, da validade e da eficácia. Nesse sentido, esclarece Antonio Junqueira de Azevedo (2013, p. 24) que “ [...] plano da existência, plano da validade e plano da eficácia são os três planos nos quais a mente humana deve sucessivamente examinar o negócio jurí- 
dico, a fim de verificar se ele obtém plena realização."

De acordo com Nathalia Masson (2006, p.169-170), a forma "segundo uma definição geral, é a modalidade através da qual a vontade do particular se manifesta no exterior".

Pois bem. Trazendo esses conceitos para o caso concreto, a primeira questão a ser aprofundada diz respeito à aptidão do meio epistolar - neste caso a Carta-Compromisso - para atender ao requisito de forma legalmente previsto. Para essa avaliação, importante trazermos a previsão constante do art. 4. ${ }^{\circ}$ da Lei n. 9.307/96, in verbis:

Art. $4^{\circ}$ A cláusula compromissória é a convenção através da qual as partes em um contrato comprometem-se a submeter à arbitragem os litígios que possam vir a surgir, relativamente a tal contrato.

$\S 1^{\circ}$ A cláusula compromissória deve ser estipulada por escrito, podendo estar inserta no próprio contrato ou em documento apartado que a ele se refira.

$\S 2^{\circ}$ Nos contratos de adesão, a cláusula compromissória só terá eficácia se o aderente tomar a iniciativa de instituir a arbitragem ou concordar, expressamente, com a sua instituição, desde que por escrito em documento anexo ou em negrito, com a assinatura ou visto especialmente para essa cláusula.

De acordo com o referido dispositivo legal, portanto, no que tange à forma da cláusula compromissória, a exigência se resume à necessidade de ser estipulada por escrito.

Prossegue o referido dispositivo indicando, ainda, que a cláusula compromissória pode estar prevista no próprio contrato em que ela está inserida ou em documento apartado que se refira ao contrato objeto de potenciais controvérsias que possam surgir.

Em contratos de adesão, exige a lei, todavia, que o aderente tenha a iniciativa de instituir arbitragem ou concorde expressamente com a sua instituição, desde que por escrito em docu- 
mento anexo ou em negrito.

No caso concreto objeto do julgado do STJ, a corte superior afastou corretamente a caracterização de contrato de adesão entre os agentes envolvidos e reconheceu que a Carta-Compromisso representaria "documento apartado", em linha com a exigência legal prevista no Art. $4^{\circ}, \S 1^{\circ}$, da Lei de Arbitragem, que impõe a forma escrita, indicando, ainda, que a convenção pode estar estipulada em documento apartado. Sobre esse ponto, assim se pronunciou o Relator:

De se destacar que a manifestação de vontade das partes contratantes, destinada especificamente a anuir com a convenção de arbitragem, pode se dar, de igual modo, de inúmeras formas, e não apenas por meio da aposição das assinaturas das partes no documento em que inserta, tal como impropriamente compreendeu o Tribunal de origem. Absolutamente possível, por conseguinte, a partir do contexto das negociações entabuladas entre as partes, aferir se elas, efetivamente, assentiram com a convenção de arbitragem. Com essa exegese, a doutrina especializada não diverge no tocante à possibilidade de a cláusula compromissória encontrar-se inserta em documento apartado do instrumento contratual a ele relacionado, inclusive em correspondências, telegramas etc, casos em que a aceitação do destinatário deve encontrar-se, por qualquer outro meio, devidamente demonstrado.

Nesse ponto, acertou o STJ ao afastar o argumento adotado pelo Tribunal a quo no sentido de que não havia concordância expressa do Autor quanto à instituição de arbitragem no Acordo de Unificação, na medida em que o art. $4^{\circ}, \S 1^{\circ}$, da Lei de Arbitragem permite que a convenção de arbitragem seja aposta em documento apartado que se refira ao contrato, como ocorreu na Carta-Compromisso, instrumento epistolar anexo e, portanto, integrante do r. Acordo de Unificação. Logo, se a Carta-Compromisso representava documento anexo ao Acordo de Unificação, instrumento devidamente assinado pelas partes contratan- 
tes, não há o que se falar em ausência de concordância expressa. Ademais, a exigência de assinatura da cláusula compromissória em instrumento específico apartado aplica-se apenas para contratos de adesão, nos termos do $\S 2^{\circ}$ do Art. $4^{\circ}$ da Lei de Arbitragem, o que não é o caso. Acertada, portanto, a decisão do STJ no sentido de afastar o referido dispositivo à espécie.

Ato contínuo, o STJ entendeu que o requisito legal de forma foi atendido, ou seja, que a suposta convenção de arbitragem foi estipulada por escrito na medida em que a Carta Compromisso, integrante do Acordo de Unificação como anexo, previu a indicação de terceiros, cuja decisão teria efeito vinculativo e caráter definitivo. Este entendimento em relação à forma de exteriorização da cláusula compromissória está respaldado não somente pela Lei de Arbitragem, como também pela Convenção de Nova Iorque, da qual o Brasil é signatário, que é expressa ao estabelecer em seu art. 20, II, que "entender-se-á por "acordo escrito" uma cláusula arbitral inserida em contrato ou acordo de arbitragem, firmado pelas partes ou contido em troca de cartas ou telegramas".3.

Ressaltamos que, neste momento, estamos tratando da forma - e não sobre o conteúdo e alcance da referida disposição pactuada entre as partes. Na seção seguinte, será tratada a natureza jurídica da referida disposição lançada na Carta-Compromisso, à luz da efetiva vontade das partes contratantes.

\section{A CONVENÇÃO DAS PARTES}

Como relatado acima, a conclusão alcançada pelo voto vencedor do referido Acórdão foi no sentido de que as partes, ao indicarem avaliadores para a aferição, em caráter vinculante e definitivo, do preço de mercado das ações da Norsul, entabularam cláusula compromissória de arbitragem apta a subtrair do Poder

3 A referida convenção foi promulgada pelo Decreto $n^{\circ} 4.311$, de 23 de julho de 2002. 
Judiciário a análise da controvérsia (efeito negativo). Ousamos dissentir da referida conclusão, pelas razões a seguir expostas.

A possibilidade de as partes contratantes indicarem terceiro para fixação de preço em contrato de compra e venda, como é o caso, está prevista no art. 485 do Código Civil de 2002, in verbis:

Art. 485. A fixação do preço pode ser deixada ao arbítrio de terceiro, que os contratantes logo designarem ou prometerem designar. Se o terceiro não aceitar a incumbência, ficará sem efeito o contrato, salvo quando acordarem os contratantes designar outra pessoa.

O "terceiro" a que se refere o dispositivo, por óbvio, é um profissional técnico, cuja responsabilidade precípua é a realização da um escopo técnico para viabilizar o aperfeiçoamento de um negócio jurídico desejado pelas partes, no caso a compra e venda da participação acionária objeto da Opção de Venda.

A doutrina diverge acerca da natureza do contrato que vincula este terceiro avaliador às partes integrantes da relação jurídica de compra e venda, ou seja, se o revestimento é de contrato de mandato, ou se de simples designação de atividade pericial. De todo modo, em qualquer caso, não se está falando em atribuição a terceiro de prerrogativa de solução de controvérsia cuja decisão tem força de título executivo judicial, como se dá na decisão proferida em sede de arbitragem.

Não há dúvidas de que há diferença entre a figura do "arbitrador" ou "avaliador" da figura do "árbitro". Nesse sentido, leciona Carlos Alberto Carmona (2009, p. 228):

Árbitro é a pessoa física indicada pelas partes-ou por delegação delas-para solucionar uma controvérsia que envolva direito disponível. Arbitrador, por sua vez, é a pessoa física indicada pelos contratantes (partes, portanto, num contrato, e não numa demanda) para integrar o conteúdo de um negócio jurídico (ou para integrar o conteúdo de uma disposição de última vontade deixada incompleta pelo testador). O ter- 
ceiro, nesta última hipótese, não decide uma controvérsia entre as partes, resolvendo-se sua atividade apenas na eliminação de um contraste de opiniões, colaborando para a formação de um negócio jurídico. São diversas, bem se vê, a atividade do árbitro e a do arbitrador: o primeiro soluciona um litígio, impondo a solução autoritativamente, declarando a norma que incidiu sobre um dado fato típico; o segundo, ao contrário, integra, com sua vontade, o negócio jurídico incompleto, limitando-se à composição de interesses conflitantes. A distinção entre árbitro e arbitrador continua a ser relevante nos dias que correm, e não por questões meramente acadêmicas. Trata-se de estabelecer e precisar funções e atividades diferentes (e para isto serve a linguagem técnica). Quem nomeia um arbitrador não quer substituir a atividade jurisdicional estatal pela privada, mas almeja completar um negócio jurídico que nasceu (ou se tornou) incompleto: seria o caso de estipular o preço do bem vendido, ou delimitar o objeto do contrato. Quem nomeia árbitro certamente está buscando uma decisão autorizativa para o caso concreto, e espera uma sentença, com os mesmos requisitos e atributos da decisão emanada do Estado.

No mesmo sentido, Luiz Olavo Baptista (2001, p. 29):

[...] O arbitramento é modo de determinação de um elemento material do negócio jurídico. Nele, as partes decidem que um terceiro estimará o preço, a qualidade ou outro elemento qualquer do negócio, integrando suas vontades. Não tem caráter decisório e pode ser objeto de revisão judicial. É ato estimatório de valores ou qualidades.

$\mathrm{O}$ fato de as partes terem estipulado no caso concreto que a decisão dos avaliadores seria vinculativa e definitiva às partes contratantes não significa que elas desejaram instituir arbitragem. Na verdade, esta disposição deve ser interpretada no sentido de que as partes optaram por delegar a um terceiro o escopo específico de definir, com caráter de solução técnica definitiva, um elemento de aperfeiçoamento do negócio jurídico, qual seja, o preço, sem prejuízo de, no caso de discordância, submeter o tema à jurisdição cabível. $\mathrm{O}$ expediente contratado, 
portanto, é similar a um trabalho pericial, que levaria em consideração aspectos econômicos e financeiros para a aferição do preço de mercado da participação acionária, atividade bastante conhecida no universo empresarial como "valuation", desenvolvida especialmente por bancos.

A decisão dos avaliadores acerca do preço de mercado da Norsul teria efeito obrigacional, restando assegurado às partes, a nosso sentir, a prerrogativa de levar eventual discordância e/ou resistência ao cumprimento da obrigação após a definição do preço à apreciação do Poder Judiciário, ou à arbitragem, se assim desejarem.

A questão do caráter vinculante e definitivo da decisão dos avaliadores é mero desdobramento da escolha das partes em fazer uso da prerrogativa prevista no art. 485 do Código Civil, que autoriza a possibilidade de as partes renunciarem ao direito de impugnação do laudo, que, na prática, equivale em atribuir caráter definitivo ao laudo produzido pelo avaliador.

Sobre esse ponto, ensina Carlos Roberto Gonçalves (2009, p. 199-200):

Se as partes expressamente convencionarem submeter-se ao preço fixado por terceiro que escolherem, implicitamente renunciam ao direito de impugnar o laudo que este apresentar. Não têm o direito de repudiar a sua estimativa, que se torna obrigatória. Todavia, o preço não poderá ser desarrazoado, contrários às legítimas expectativas dos contratantes ou em desarmonia com as circunstâncias que devam ser levadas em conta. Embora a estimação feita pelo terceiro não possa ser reduzida, é ressalvado a qualquer dos contratantes o direito de demandar a nulidade do contrato por dolo.

Solução similar ocorre quando se estipula previsão de submissão de controvérsia a Dispute Adjudication Boards, painéis usualmente previstos em contratos de construção, que são compostos por profissionais técnicos cuja responsabilidade é acompanhar a execução de contratos e endereçar controvérsias 
mediante emissão de recomendações que são vinculativas às partes contratantes (neste modelo de Dispute Board). No caso dessas recomendações, entende-se que são vinculativas às partes, obrigando-as, mas de forma alguma eliminam a prerrogativa de submissão da controvérsia à apreciação jurisdicional (judiciário ou arbitragem).

O voto vencido proferido pelo Min. Ricardo Villas Bôas Cueva no âmbito do referido Acórdão foi bastante assertivo ao estatuir que a cláusula remete à nomeação de avaliadores do bem, e não à suposta pretensão das partes em relação ao método de resolução de conflitos.

Caso as partes contratantes, agentes privados que entabularam negócio jurídico da alta sofisticação e complexidade, certamente assessoradas por escritórios de advocacia de renome, desejassem estabelecer disposição segundo a qual as controvérsias decorrentes do Acordo de Unificação de sociedades de navegação e seus anexos fossem submetidas à arbitragem, teriam o feito expressamente, sem abrir margens para extensão dialética acerca de uma cláusula que nitidamente reflete o art. 485 do Código Civil vigente (redação idêntica do ant. 1.123 do Código Civil de 1916). Neste caso, a opção das partes contratantes foi no sentido de submeter as controvérsias à jurisdição estatal, pois ausente qualquer cláusula compromissória.

Outro argumento pouco explorado pelo voto vencedor, mas acertadamente levantado pelo voto vencido, diz respeito à existência de outras divergências que extrapolam a controvérsia acerca do valor de mercado das ações, como é o caso do ponto relativo à base de cálculo para a incidência do percentual de participação acionária a ser transferida mediante o exercício da Opção de Venda-se recairiam somente sobre as ações de titularidade do Autor ou sobre a totalidade das ações da companhia. O trecho abaixo do voto vencido explora com precisão este ponto, in verbis: 
Dessa circunstância sobressai não só a nítida presença de interesse processual do autor da demanda, como também a conclusão de que a lide em comento desborda da mera discordância de eventual decisão dos avaliadores, denotando que a cláusula em apreço jamais teria o alcance de subtrair do Poder Judiciário o litígio que se estabeleceu entre as partes.

De fato, compulsando detidamente os autos, verifica-se que a matéria controvertida ultrapassa a simples divergência sobre o valor de mercado das ações da Norsul.

Da leitura da inicial e da contestação, nota-se que há controvérsia também quanto à base de cálculo do percentual de $7 \%$ das ações: se recairiam somente sobre as ações a cargo do recorrido ou sobre a totalidade das ações da companhia.

Nesse aspecto, não há efetivamente nenhuma margem para falar em qualquer cláusula arbitral.

Ora, existindo outras divergências advindas da Carta-Compromisso, a exemplo da base de cálculo para a incidência do percentual de $7 \%$ da participação acionária do Autor, não há como sustentar que a disposição acerca da nomeação de um terceiro, vinculada estritamente ao item relativo ao preço de mercado da Norsul, deve ser aplicável para endereçar outros pontos que, vale dizer, extrapolam o trabalho técnico contratado pelas partes, já que decorre de uma análise estritamente jurídica - definição da base de cálculo à luz dos instrumentos celebrados entre as partes.

Essa questão motivou o posicionamento do Min. João Otávio de Noronha no sentido de acompanhar em parte o voto do relator para "reconhecer o caráter compromissório da cláusula atinente à fixação do valor das ações, devendo, contudo, o feito prosseguir em relação à outra questão controvertida."

Observem a situação no mínimo inusitada que o entendimento acerca da existência de cláusula compromissória para definir o valor de mercado da Norsul poderia levar: o valuation da Norsul seria submetido à suposta jurisdição arbitral e a definição da base de cálculo seria remetida à apreciação do 
Poder Judiciário, sendo que os assuntos têm vinculação intrínseca para a operacionalização da Opção de Venda. Será que as partes desejavam esta cisão completamente ineficiente para materializar a Opção de Venda? No limite, será que as partes efetivamente desejavam submeter o tema a um procedimento arbitral oneroso e demorado ${ }^{4}$ para a definição de um aspecto estritamente técnico? Parece-nos que não.

Seguindo esta linha de raciocínio, reportamo-nos a regra contida no art. 112 do Código Civil, segundo o qual nas declarações de vontade se atenderá mais à intenção nelas consubstanciada do que ao sentido literal da linguagem.

Nesse contexto, não conseguimos depreender da disposição contida na Carta-Compromisso, em que as partes atribuem a terceiros avaliadores a tarefa de aferir o preço de mercado da Norsul, cuja decisão será vinculativa e definitiva, a conclusão segundo a qual as partes teriam entabulado cláusula compromissória.

Primeiro, porque o conceito de avaliador não se confunde com árbitro, estando equivocada a assertiva lançada no voto vencedor de que "é irrelevante, o termo utilizado na avença (avaliador, arbitrador etc) ". Com efeito, o Código Civil (tanto o Código Civil de 1916 quanto o Código Civil de 2002) prevê expressamente a possibilidade de as partes, em contratos de compra e venda, elegerem terceiro para a fixação do preço, como é exatamente o caso.

A disposição visa atribuir às partes a escolha de um profissional para endereçar elemento categorial fundamental para o aperfeiçoamento do contrato de compra e venda - o preço, e não diz respeito, em hipótese alguma, a questões relacionadas à solução de controvérsias mediante adoção de jurisdição pri-

4 Muito embora uma das vantagens da arbitragem seja a celeridade, um procedimento arbitral pode levar mais de 2 (dois) anos. 
vada, em renúncia à jurisdição estatal.

Vale dizer, ainda, que a sua interpretação da referida disposição, conforme dispõe o art. 114 do Código Civil de 2002, deveria ter sido a mais restritiva possível, na medida em que a adoção de cláusula compromissória significa renúncia à jurisdição estatal, como decorrência do denominado efeito negativo da convenção de arbitragem. Logo, o STJ, em hipótese alguma, poderia ter interpretado a referida disposição de modo a atribuir-lhe a natureza de cláusula compromissória.

Segundo, porque muito embora tenha sido atribuída eficácia vinculante e definitiva à decisão dos referidos avaliadores, esta disposição tem projeção meramente obrigacional, não afastando, em hipótese alguma, a revisão do tema em sede jurisdicional, no caso, pela via do Poder Judiciário, já que ausente qualquer disposição no sentido de dispor acerca de cláusula compromissória. E terceiro, a referida disposição não materializa vontade das partes de entabularem cláusula compromissória.

Nessa conjuntura, reportamo-nos aos princípios da autonomia privada e do consensualismo, que devem reger o instituto da arbitragem. A escolha relativa à submissão de controvérsias decorrentes do contrato à jurisdição privada deve ser fruto de inequívoco e livre consentimento das partes contratantes. Essa á a razão de existir do instituto da arbitragem.

Com efeito, o instituto da arbitragem deve ser interpretado de modo que seja efetivamente aplicado quando decorrer da livre e inequívoca escolha das partes, como também afastado quando não existir elementos que demonstrem e indiquem o consentimento das partes no sentido de renunciarem à jurisdição estatal mediante a escolha da jurisdição privada.

Em suma, entendemos que a disposição contida na Carta-Compromisso não tem natureza jurídica de cláusula compromissória, ao contrário do que compreendeu o STJ no bojo 
do Acórdão objeto do presente artigo.

\section{PRINCÍPIO DA COMPETÊNCIA- COMPETÊNCIA NO CASO CONCRETO}

$\mathrm{O}$ voto vencedor do referido Acórdão também trouxe como fundamento para a extinção do processo sem a resolução do mérito a incidência do princípio da competência-competência, previsto no art. $8^{\circ}$, parágrafo único da Lei de Arbitragem, segundo o qual, cabe ao árbitro analisar as questões relativas à existência, validade e eficácia da convenção de arbitragem. Este é o teor do referido dispositivo:

Art. $8^{\circ}$ A cláusula compromissória é autônoma em relação ao contrato em que estiver inserta, de tal sorte que a nulidade deste não implica, necessariamente, a nulidade da cláusula compromissória.

Parágrafo único. Caberá ao árbitro decidir de ofício, ou por provocação das partes, as questões acerca da existência, validade e eficácia da convenção de arbitragem e do contrato que contenha a cláusula compromissória. (Grifo nosso).

Assim se posicionou o Relator:

Destaca-se, pois, que a lei de regência confere ao juízo arbitral a medida de competência mínima, veiculada no Princípio da Komptetenz Kompetenz, cabendo-lhe, assim, deliberar sobre a sua própria competência, precedentemente a qualquer outro órgão julgador, imiscuindo-se, para tal propósito, sobre as questões relativas à existência, à validade e à eficácia da convenção da arbitragem e do contrato que contenha a cláusula compromissória, o que deve ser detidamente observado na hipótese dos autos.

Cabe esclarecer que a razão de existir do referido dispositivo legal reside no objetivo de impedir que partes signatárias de um contrato em que há cláusula compromissória, buscando evadir-se de se submeterem ao juízo arbitral, buscassem provocar o judiciário para atacar questões relativas à existên- 
cia, validade e eficácia do contrato, neutralizando os efeitos imediatos da cláusula compromissória. O referido princípio está visceralmente relacionado ao princípio da autonomia da cláusula compromissória. Sobre o princípio, leciona Francisco José Cahali (2013, p. 107):

Tratado como o princípio da competência-competência, seu acolhimento significa dizer que, com primazia, atribui-se ao árbitro a capacidade para analisar sua própria competência, ou seja, apreciar, por primeiro, a viabilidade de ser por ele julgado o conflito, pela inexistência de vício na convenção ou no contrato.

Esta regra é de fundamental importância ao instituto da arbitragem, na medida em que, se ao Judiciário coubesse decidir, em primeiro lugar, sobre a validade da cláusula, a instauração do procedimento arbitral restaria postergada por longo período, e, por vezes, apenas com o intuito protelatório de uma das partes em esquivar-se do cumprimento da convenção. $O$ princípio, desta maneira, fortalece o instituto, e prestigia a opção das partes por esta forma de solução de conflitos, e afasta, em certa medida, o risco de desestímulo à contratação da arbitragem, em razão de potencial obstáculo prévio a surgir no Judiciário diante da convenção, por maliciosa manobra de uma das partes. (Grifo nosso).

$\mathrm{O}$ voto do Relator, que restou vencedor no r. Acórdão, adotou o referido princípio como fundamento para determinar que o árbitro, conforme cláusula compromissória supostamente adotada pelas partes, decida sobre a existência, validade e eficácia da alegada cláusula compromissória. Data máxima vênia, não concordamos com a aplicação do referido princípio à espécie.

O princípio da competência-competência não tem caráter absoluto. A doutrina vem identificando situações em relações às quais, uma vez identificado um vício prima facie da disposição, conceito este que abrange a ausência de declaração de vontade no sentido de instituir arbitragem, estaria o judiciário autorizado 
a apreciar diretamente a controvérsia, afastando o redirecionamento da lide à jurisdição arbitral, posto que não escolhida pelas partes. Nesse sentido, mais uma vez fazemos referência aos ensinamentos de Francisco José Cahali (2013, p. 108):

Em situações especiais, como nos casos em que a instauração do procedimento arbitral se fará por indicação do juízo estatal em cumprimento da cláusula compromissória vazia (art. $7^{\circ}$ da Lei 9.307/1996), a convenção será previamente analisada pelo Judiciário, de forma superficial, tal como também acontece quando uma das partes ingressa com a ação no juízo estatal e a outra parte invoca a existência de cláusula compromissória com o objetivo de se extinguir o processo, sem julgamento de mérito (art. 267, III c/c art. 301, IX, do CPC). Verificada, prima facie, gritante vício na convenção ou no próprio contrato, objetivamente apurado, tem sido admitido o reconhecimento judicial nesta oportunidade.

Como exceção à regra, a análise é circunstancial, ou seja, dependerá de quanto apresentado na hipótese submetida a exame. O relevante é saber que, diante de uma anomalia evidente, detectada primoictuoculi, há que se admitir a avaliação prévia (ou concomitante) do vício pelo Judiciário, permitindo-lhe até mesmo, se o caso, seguir à apreciação do mérito do conflito. (Grifo nosso).

No mesmo sentido, Giovanni Ettore Nanni (2014, p. 29):

Apesar de tal dispositivo, pensa-se que ele não é absoluto, devendo ser conjugado com, ao menos, um elemento básico e instituidor do negócio jurídico, que é a declaração de vontade de pactuar a cláusula compromissória.

$\mathrm{Se}$, de fato, compete ao árbitro decidir a respeito de sua própria competência, bem como se cabe a ele deliberar sobre a inexistência, a invalidade e a ineficácia da cláusula compromissória, abarcando, por conseguinte, a atribuição de julgar sobre toda sorte de patologia de tal pacto, na hipótese de anomalia extrema a solução deve ser outra, em nome da segurança jurídica.

A ausência de declaração de vontade apta a forma a cláusula compromissória equivale a uma anomalia extrema, dig- 
no exemplo teratológico, que não deve dar azo a uma válida constituição de um procedimento arbitral. (Grifo nosso).

E, por fim, Carlos Alberto Carmona (2009, p. 177) aborda o mesmo tema:

A doutrina, de qualquer forma, ainda não tem posicionamento firme no sentido de identificar com exatidão quais os limites dos poderes investigativos do juiz acerca da invalidade da convenção de arbitragem. Emmanuel Gaillard sugere que o juiz só possa declarar a invalidade da convenção arbitral quando o vício for reconhecível prima facie, ou seja, de pronto, sem necessidade de maior exame. Parece que o ilustre professor parisiense tem razão, já que a limitação da cognição do juiz apenas a aspectos que desde logo pode detectar, sem maiores indagações (cognição sumária, portanto), harmoniza-se com o princípio da Kompetenz-Kompetenz adotado pela lei.

Nesse contexto, embora sejamos guardiões do princípio da competência-competência, tendo em vista a sua importância para assegurar a efetividade do instituto da arbitragem, entendemos que o art. $8^{\circ}$, parágrafo único da Lei de Arbitragem - dispositivo legal que o corporifica - não deveria ter sido aplicado ao caso concreto apreciado pelo STJ, diante da absoluta ausência de declaração de vontade no sentido de instituir arbitragem.

É bem verdade que vozes surgirão em sentido contrário para sustentar que a disposição constante da Carta-Compromisso gera dúvida razoável e, segundo princípio favor arbitral, a questão relativa à existência de cláusula compromissória no caso concreto deveria, de fato, ser apreciada pelo juízo arbitral, sem prejuízo de controle posterior do judiciário. Ocorre que, no presente caso, não há dúvida de que a referida disposição não representa cláusula compromissória e, por esta razão, submeter às partes a um oneroso procedimento que pode ser anulado posteriormente no judiciário, pode representar violação aos princípios do acesso à justiça, celeridade processual e devido processo legal. 
A aplicação desmesurada do princípio da competênciacompetência pode conduzir a situações extremas, em que, no limite, qualquer disposição com redação pouco precisa, pode ser interpretada para fazer demonstrar inexistentes configurações de cláusula compromissória.

\section{CONCLUSÃO}

Diante do exposto, podemos extrair as seguintes conclusões:

a. A disposição contida na Carta-Compromisso atendeu ao requisito legal da forma, na medida em que foi lançada por escrito em documento apartado ao contrato, em conformidade com a Lei de Arbitragem.

b. O pacto das partes foi no sentido de atribuir a terceiro a tarefa técnica/pericial de definir o preço de mercado da participação acionária a ser objeto de alienação pelo Autor em favor dos Réus, conforme autoriza o Código Civil em seu art. 485.

c. O fato de as partes terem disposto que o resultado desta avaliação, entendido como um laudo técnico, teria caráter definitivo e vinculativo representa avença com projeção meramente obrigacional, não retirando das partes a prerrogativa de questionar o resultado do laudo em sede jurisdicional.

d. As partes não estabeleceram cláusula compromissória, mas apenas a sistemática de atribuição a terceiro da atribuição de definir o preço de mercado das ações, de modo a aperfeiçoar o negócio jurídico de compra e venda.

e. O princípio da competência-competência não deveria ter sido aplicado ao caso concreto, em razão da flagrante inexistência de declaração negocial de instituir cláusula compromissória.

Diante de todo o exposto, esperamos que a presenta abor- 
dagem acerca do r. Acórdão proferido pelo STJ possa despertar a reflexão sobre a adequada interpretação acerca do requisito de forma da cláusula compromissória, do art. 485 do Código Civil (redação idêntica do art. 1.123 do Código Civil de 1916) e do princípio da competência-competência previsto no art. $8^{\circ}$, parágrafo único da Lei de Arbitragem.

\section{REFERÊNCIAS}

ALVIM, José Eduardo Carreira. Direito arbitral. 2. ed. Rio de Janeiro: Forense, 2004.

AZEVEDO, Antônio Junqueira. Negócio jurídico: existência, validade e eficácia. 4. ed. São Paulo: Saraiva, 2013.

BAPTISTA, Luiz Olavo. Arbitragem comercial e internacional. São Paulo: Lex Editora, 2011.

CAHALI, Francisco José Cahali. Curso de arbitragem: resolução CNJ 125/2010 (e respectiva emenda de 31 de janeiro de 2013): mediação e conciliação. 3. ed. Revista dos Tribunais: São Paulo, 2013.

CARMONA, Carlos Alberto. Arbitragem e processo. 3. ed. São Paulo: Atlas, 2009.

GONÇALVES, Carlos Roberto. Direito civil brasileiro. Volume III: contratos e atos unilaterais. 6. ed. São Paulo: Saraiva, 2009.

MASSON, Nathalia. O princípio da liberdade das formas. In: MORAES, Maria Celina Bodin de. (Coord.). Princípios do direito civil contemporâneo. Rio de Janeiro, 2006.

NANNI, Giovanni Ettore. Direito civil e arbitragem. São Paulo: Atlas, 2014.

Artigo recebido em: 12/04/2017

Artigo aprovado em: 04/10/2017 